\title{
International Coordination in Managing Airborne Ash Hazards: Lessons from the Northern Pacific
}

\author{
Yohko Igarashi, Olga Girina, Jeffrey Osiensky \\ and Donald Moore
}

\begin{abstract}
Airborne volcanic ash is one of the most common, far-travelled, direct hazards associated with explosive volcanic eruptions worldwide. Management of volcanic ash cloud hazards often requires coordinated efforts of meteorological, volcanological, and aviation authorities from multiple countries. These international collaborations during eruptions pose particular challenges due to variable crisis response protocols, uneven agency responsibilities and technical capacities, language differences, and the expense of travel to establish and maintain relationships over the long term. This report introduces some of the recent efforts in enhancing international cooperation and collaboration in the Northern Pacific region.
\end{abstract}

Y. Igarashi $(\bowtie)$

Seismology and Volcanology Department, Japan Meteorological Agency (JMA), Tokyo, Japan e-mail: y_igarashi@met.kishou.go.jp

O. Girina

Kamchatka Volcanic Eruption Response Team (KVERT), Petropavlovsk-Kamchatsky, Russia

J. Osiensky

Environmental and Scientific Services Division, National Oceanic and Atmospheric Administration, National Weather Service (NOAA/NWS) Alaska Region, Silver Spring, USA

D. Moore

Volcanic Ash Advisory Centre (VAAC) Anchorage, National Oceanic and Atmospheric Administration, National Weather Service (NOAA/NWS) Alaska

Region, Silver Spring, USA

\section{Introduction}

Airborne volcanic ash is one of the most common, far-travelled, direct hazards associated with explosive volcanic eruptions worldwide. Management of volcanic ash cloud hazards often require coordinated efforts of meteorological, volcanological, and civil aviation authorities from multiple countries. These international collaborations during eruptions pose particular challenges due to variable crisis response protocols, uneven agency responsibilities and technical capacities, language differences, and the expense of travel to establish and maintain relationships over the long term. The steady rise in global aviation, particularly on the remote routes between North America and Asia that overfly more than 100 potentially active volcanoes in the 


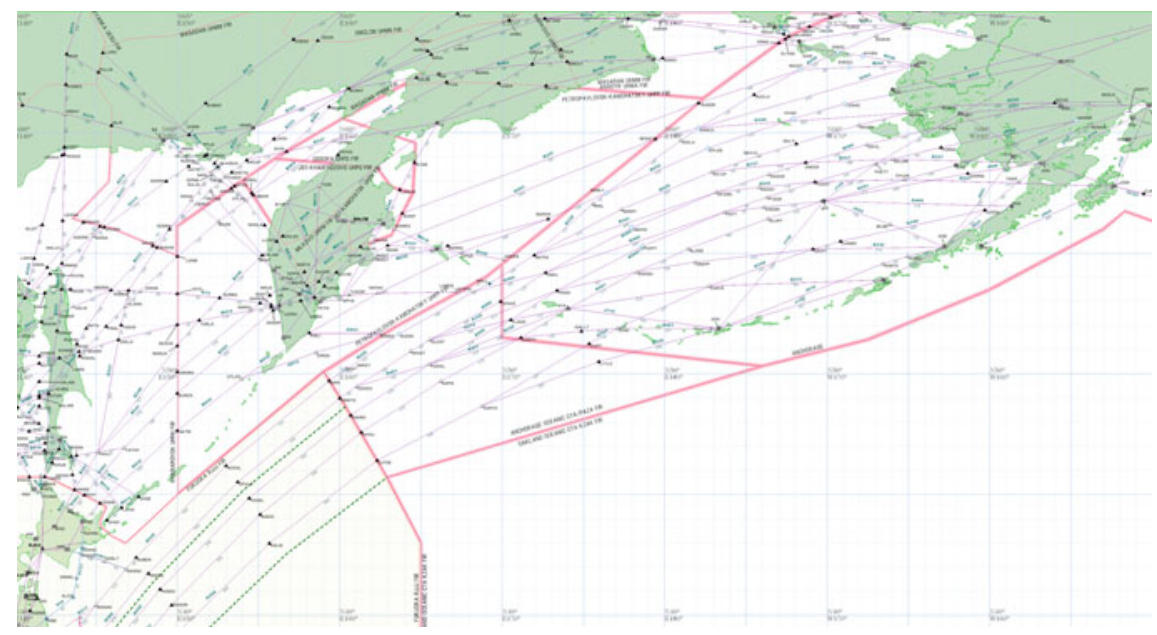

Fig. 1 Route map in the Northern Pacific region

United States (Alaska and Aleutian Islands) and the Russian Federation (Kamchatka and Kurile Islands), means that more and more aircraft are at risk from the impacts of airborne volcanic ash.

The Northern Pacific (NOPAC) air routes connecting Alaska to the far east (Fig. 1) carry 10,000 people per day and up to 50,000 aircraft per year with some routes passing over the Kamchatka Peninsula with around 30 volcanoes (Gordeev and Girina 2014; VAAC Anchorage 2015a). Commercial aircraft in this region are required to operate on a fixed route and flight level approved by Air Navigation Service Providers (ANSPs). They need an approval before or during a flight when they change their route and/or flight level; re-routing to avoid a volcanic eruption is no exception. Over the past two decades, more than 60 strong explosive eruptions in the Russian Far East (Girina et al. 2007, 2009, 2014a, b; Gordeev and Girina 2014; McGimsey and Neal 1996; McGimsey and Wallace 1999; McGimsey et al. 2003, 2004a, b, 2005, 2008, 2011, 2014; Neal and McGimsey 1997; Neal et al. 2004, 2005a, b, 2009a, b, 2011, 2014) have tested coordination among relevant agencies and institutions in Japan, the Russian Federation, the United States, and Canada, prompting ongoing testing of existing systems with a number of lessons learned. Critical to meeting this challenge of a rapid, international response to volcanic ash cloud hazard is development of written, updated, and practiced response plans or agreements detailing roles and responsibilities.

Frequent exercises that test the readiness and procedures, involving representatives of international air carriers, are important tools to continually refine the response process. A mechanism to engage air carriers and critically evaluate individual eruption responses to events is also necessary to focus these improvements. Each of the three main components of ash cloud response: meteorology, volcanology, and air traffic management, have different challenges in obtaining a seamless coordinated response. The establishment of a worldwide system of Volcanic Ash Advisory Centres (VAACs) in the mid-1990s assisted greatly in development of a consistent meteorological response and warning product suite. Similarly, the mature system of international conventions in air traffic management contributes significantly to coordinated handling of air traffic during eruptions that may disrupt the air routes. However, there remains strong variability in the adequacy of volcano surveillance and alerting by appropriate regional volcanological authorities, a challenge increasingly met by the growing use of remote and satellite based monitoring and eruption detection techniques. Recent eruptions of Sarychev-Peak Volcano in 2009 (McGimsey et al. 2014) and Kliuchevskoi 
Volcano in 2013 (Girina et al. 2014a, b) illustrate aspects of both the successes and ongoing challenges of international eruption response in the Northern Pacific, as well as worldwide.

\section{VAACs and Volcano Observatories Related to Volcanic Ash Clouds in the Northern Pacific Region}

To avoid aircraft-related disasters caused by volcanic ash clouds, a framework for the International Airways Volcano Watch (IAVW) was established in 1993 by the International Civil Aviation Organization (ICAO). Under this framework, nine VAACs were designated as centres to monitor volcanic eruptions and to provide information on the locations and movement of volcanic ash clouds as well as an outlook for their regions of responsibility (Fig. 2). In the Northern Pacific region, there are four VAACs: Anchorage, Montreal, Tokyo and Washington. Among them, VAAC Anchorage has the area of responsibility covering the entire Anchorage Flight Information Region (FIR) as well as an area bounded on the west by $150^{\circ} \mathrm{E}$ Longitude and on the south by $60^{\circ} \mathrm{N}$ Latitude, which includes all the volcanoes within the State of Alaska. VAAC Anchorage's area of responsibility is adjacent to volcanoes located in Kamchatka Peninsula and the Northern Kurile Islands, which are in the area of responsibility of VAAC Tokyo that covers the East Asia and Northwest Pacific regions. Several volcanoes in the region are quite active and ash clouds often move across the boundary of the area of responsibility of these two VAACs where the VAACs hand over the responsibility of information issuance through close coordination and communication. This chapter mainly highlights the activities of these two VAACs and related organizations in the region.

VAAC Anchorage was established by the United States Department of Commerce (DOC) National Oceanic and Atmospheric Administration's (NOAA) National Weather Service (NWS) at the request of the Federal Aviation Administration (FAA). It has been providing information on volcanic ash clouds in the form of Volcanic Ash Advisories (VAAs) around the clock, supporting the Anchorage Meteorological Watch Offices (MWO) and the Anchorage Area Control Center (ACC).

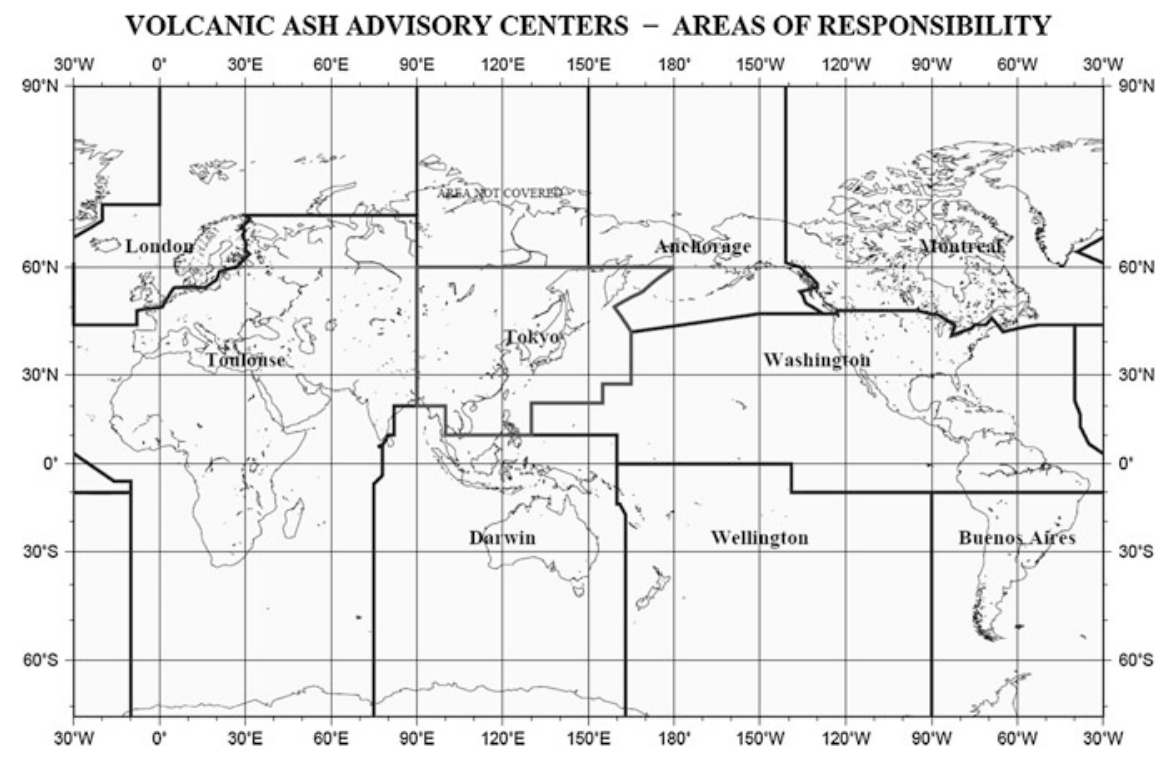

Fig. 2 Areas of responsibility of all VAACs as of October 2016 
VAAC Tokyo has been monitoring volcanoes around the clock and issuing VAAs since 1997. It is a part of the Japan Meteorological Agency (JMA). VAAC Tokyo was originally established in the Tokyo Aviation Weather Service Center, the branch office of JMA located at Haneda Airport, and was transferred to JMA headquarters in Tokyo in 2006. Through the experience of several significant eruptions such as that of Sarychev Peak in 2009, VAAC Tokyo strengthened the operations by allocating five forecasters specific for volcanic ash in 2011, while not all VAACs have their own forecasters (in such VAACs, forecasters share other aviation duties, too). VAAC Tokyo supports MWO Tokyo, also a part of JMA, as well as the ACCs in the area (JMA/VAAC Tokyo 2015).

As for VAAC operations, early detection of volcanic eruptions is crucial. To enable timely VAA provision, a VAAC monitors satellite imagery for volcanic ash clouds around the clock. Whenever a new eruption is identified, it announces the possibility of eruption through VAA issuance and continues VAA provisions until the volcanic ash cloud is dissipated. However, as satellite imagery is not continuous data, the initial detection can be delayed. For example, the new satellite of HIMAWARI-8, that was launched on October 7, 2014 and has been operational since July 7, 2015, principally provides imagery every ten minutes, and MTSAT-2, still in operation as a back-up, provides imagery twice per hour. Therefore, adding to the data from satellites, VAACs Anchorage and Tokyo also receive information about eruptions from relevant volcano organizations and sometimes from aircraft in operation. For example, the Alaska Volcano Observatory (AVO), operated conjointly by the University of Alaska and the United States Geological Survey (USGS), provides daily and weekly volcano reports to adjacent VAACs. Volcano observatories such as the Kamchatka Volcanic Eruption Response Team (KVERT) on behalf of the Institute of Volcanology and Seismology (IVS) Far East Branch of Russian Academy of Sciences and the Sakhalin Volcanic Eruption Response Team of the Institute of Marine Geology and Geophysics, provide not only daily and weekly volcano reports but also timely eruption information about volcanoes in Kamchatka Peninsula and Kurile Islands.

Volcano activities in Japan are monitored by four JMA Volcanic Observations and Warning Centers (VOWCs) located in Sapporo, Sendai, Tokyo and Fukuoka. VAAC Tokyo receives volcanic activity reports from these VOWCs immediately after eruptions. As the area of responsibility of VAAC Tokyo extends to the Philippines, the centre also receives timely information from the Philippine Institute of Volcanology and Seismology (PHIVOLCS).

Information provided by most of these volcano observatories is called "Volcano Observatory Notice for Aviation" (VONA). While periodical information is useful to grasp the latest volcanic conditions, VONAs are indispensable for timely VAA provision by VAACs, especially with regard to the initial issuances. Given volcanoes in Kamchatka Peninsula are remarkably active, VAACs Tokyo and Anchorage often issue VAAs regarding volcanic ash clouds from those volcanoes based on VONAs from KVERT.

KVERT was established in 1993 aiming at improving safety for aviation during explosive eruptions. It has a similar goal to VAACs to reduce the risk of aircraft encountering volcanic ash clouds in the Northern Pacific region through timely detection of volcanic unrest, tracking of ash clouds, and prompt notification of airlines, civil aviation authorities, and others about the hazards (Gordeev and Girina 2014; Neal et al. 2009a, b). The complex analysis of published data on volcanic activity and the data from 22 years of KVERT's continuous monitoring of volcanoes allows a quantitative evaluation of the hazard posed by volcanoes to aviation. The level of hazard to aviation from each of the Kamchatkan volcanoes is communicated by KVERT using the Aviation Colour Code recommended by ICAO (2004). When KVERT issues a VONA, it is automatically disseminated to VAACs Anchorage, Darwin, Montreal, Tokyo and Washington, and all international and local users of the Northern Pacific region such as ICAO, FAA, NOAA, AVO, USGS, the Yelizovo 
Airport Meteorological Center (Yelizovo AMC), the Kamchatka Hydro-Meteorological Center (KHMC), the Kamchatka Branch of the Ministry for Emergency Situations (KB MES), and mass media. It is also automatically uploaded on the KVERT website: http://www.kscnet.ru/ivs/kvert/ van/ (Girina and Romanova 2015).

Adding to the volcanoes in Kamchatka Peninsula, several volcanoes in Japan are also very active; therefore, VAAC Tokyo frequently issues VAAs in this regard based on VONAs from JMA's VOWCs.

Based on VONAs from volcano observatories adding to volcanic ash clouds detection in satellite imagery, VAACs issue VAAs designed to assist MWOs in preparing international standard Significant Meteorological Information (SIGMET) on volcanic ash clouds. VAAs, describing the latest extent and forecast trajectories of volcanic ash clouds, are updated every six hours so long as ash clouds are identified by satellite imagery. The VAAs are issued within the six hours if unforeseen changes occur in observations. The roles of relevant organizations and regulations of operations are given by ICAO (2007).

\section{Case Study of Impacts of a Volcano Eruption onto Air Traffic}

The impacts of volcanic eruptions are the strongest triggers for improvements in volcanic ash responses by relevant organizations because they give a true account of tasks to overcome as well as successful operations. This section shows two case study examples of major volcano eruptions and subsequent actions taken by relevant organizations.

\subsection{Case Study \#1}

Eruption of Sarychev-Peak Volcano in 2009

An eruption of Sarychev-Peak Volcano in the Kurile Islands was detected at 01:59 UTC on
June 12, 2009. VAAC Tokyo identified the eruption from satellite imagery and issued the first VAA at 06:49 UTC with an observed volcanic ash cloud at 34,000 $\mathrm{ft}$ extending to the east.

On the day of the eruption, only five aircraft requested re-routing; however, the volcanic ash cloud in the VAAC Tokyo's area of responsibility reached 54,000 $\mathrm{ft}$ the next day according to the VAA issued by VAAC Tokyo, and the volcanic ash cloud continued to be observed at that height for one and a half days. As a result of the VAAs, most flights avoided the NOPAC route and flew through Russian airspace instead.

As it was a continuous eruption with ash emission, the volcanic ash cloud extended more and more widely. It migrated into VAAC Washington's area of responsibility, also covering a small part of VAAC Anchorage's region, while volcanic ash clouds due to subsequent emissions covered VAAC Tokyo's area of responsibility. VAACs Tokyo and Washington (and later VAAC Anchorage) issued VAAs and advisories in graphic format (Volcanic Ash Graphic: VAGs) (Fig. 3). As the volcanic ash cloud covered a wide area across the NOPAC region, the Air Traffic Management Center in the Japan Civil Aviation Bureau (JCAB/ATMC) set the Pacific Organized Track System (PACOTS) avoiding the NOPAC route based on the VAAC Tokyo's advisories. Oakland Air Route Traffic Control Center (ARTCC) set westward PACOTS based on the advisories provided by VAAC Washington and requested JCAB/ATMC also to set eastward PACOTS in the same way.

The volcanic ash cloud remained relatively high even after it lowered from the maximum height. Following a request from an airline, VAAC Tokyo therefore began providing VAA/VAG every three hours instead of the regular six-hour interval from around 09:00 UTC on June 16. Under this situation, some irregular incidents occurred and JCAB/ATMC as well as the Oakland ARTCC responded to each case. For example, a particular aircraft headed into the volcanic ash cloud area without knowing the situation and JCAB/ATMC was obliged to advise re-routing. Another example was that one particular airline, flying on a regional route in 

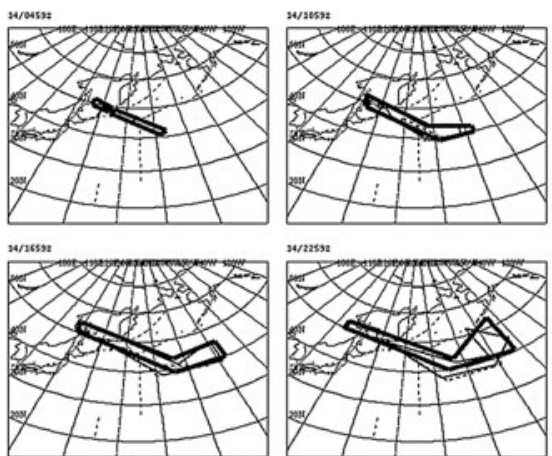

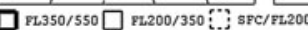

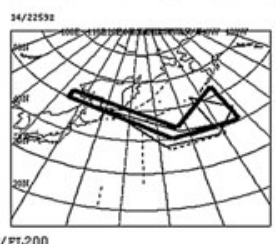

Fig. 3 VAGs by VAACs Tokyo (left) and Washington (right) issued at 06:22 UTC and 06:24 UTC on 14 June 2009, respectively, for a volcanic ash cloud covering a wide area from Sarychev-Peak Volcano in Kamchatka peninsula in VAAC Tokyo's region to VAAC Washington's area of responsibility. VAG is composed of four

Southeast Asia, wished to request rerouting, but did not know where to make a request, so JCAB/ATMC in Japan and the Oakland ARTCC coordinated with JCAB/ATMC taking the role to respond to the request. Considering the situation, JCAB/ATMC issued a NOTAM at 12:53 UTC on June 22 describing the need to collect information about the volcanic ash cloud caused by the Sarychev-Peak Volcano eruption.

VAAC Washington ended advisory provision in its area of responsibility at 05:00 UTC on June 19. VAAC Tokyo announced the volcanic ash cloud dissipation at 02:52 UTC on June 23 and the VAAC Anchorage at 07:30 UTC on June 25. As the volcanic ash cloud remained for more than ten days, the impact on aviation operations was significant.

During this event, close communication between JCAB/ATMC and the Oakland ARTCC assisted successful collaborative operations. The flexibility of VAAC Tokyo in providing VAAs every three hours instead of the regular six-hour interval was also user-friendly because airlines were able to re-route with minimum detours based on the frequently-updated advisories. However, at the same time, this event highlighted a necessity for thorough information distribution so that no aircraft operates toward the volcanic ash cloud area (McGimsey et al. 2014; JMA/VAAC Tokyo

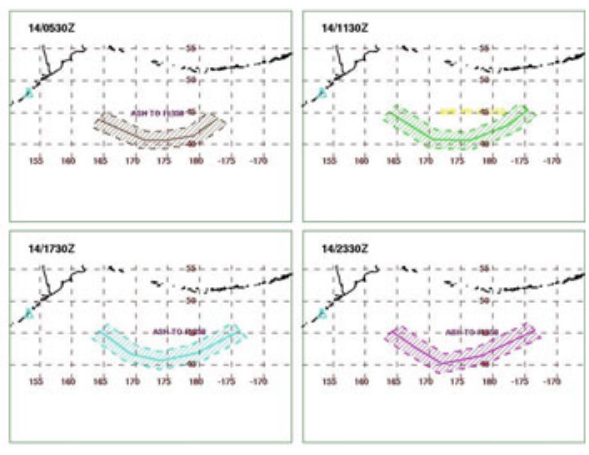

maps with volcanic ash cloud areas at present (left top), six hours ahead (right top), twelve hours ahead (left bottom) and eighteen hours ahead (right bottom), and explanatory in text. Here, only maps are extracted from the original VAGs (he texted information is not shown)

2010; NOAA/VAAC Anchorage 2015b; NOAA/VAAC Washington 2015).

\subsection{Case Study \#2}

Eruption of Kliuchevskoi Volcano in 2013

A strong explosive and effusive eruption of Kliuchevskoi Volcano in the middle of Kamchatka Peninsula started on August 15, 2013 and lasted until December 20, 2013, with repeated eruptions and ash dissipation. VONA and VAA/VAGs on November 19 reported that the ash reached above 40,000 ft; however, the paroxysmal phase of eruption on October 15-20, in which explosions sent volcanic ash up to around 30,000-33,000 ft each time, was probably the most significant phase of the activity, because the volcanic ash cloud extended across the boundary of VAACs Tokyo and Anchorage's areas of responsibility and both VAACs issued advisories for their respective areas of responsibility (Girina et al. 2014a, b; JMA/VAAC Tokyo 2014; KVERT/VONA 2013; NOAA/VAAC Anchorage 2015b).

The volcanic ash cloud moved to the southeast and partially migrated into VAAC Anchorage's area of responsibility at around 18:00 UTC 
on October 18. VAAC Anchorage then consulted with VAAC Tokyo on future plans of VAA/VAG issuances. VAAC Tokyo decided to continue VAA/VAG issuances but from 00:54 UTC on October 19, VAAC Tokyo handed over the responsibility for some part of the volcanic ash cloud, which had migrated into VAAC Anchorage's area of responsibility. The volcanic eruption continued with volcanic ash clouds continuously produced. Once VAAC Tokyo handed over the responsibility for some part of a volcanic ash cloud that had migrated into VAAC Anchorage's region, another volcanic ash cloud extended across the boundary of the VAACs areas of responsibility a few hours later, instigating another handover. In this way, the VAACs provided VAA/VAGs for their respective airspaces, that is, the ash area was divided into two following their areas of responsibility (the entire volcanic ash cloud area could not be obtained in either single VAA/VAG). In addition, each VAAC uses its own diffusion model for forecasting volcanic ash cloud areas, so the results differ slightly. For this event, the results of the two VAACs were inconsistent, each having issued VAA/VAGs for their own region without coordination with the other (Fig. 4). An airline made an inquiry as to the difference of volcanic ash cloud extent in the VAA/VAGs issued by VAACs Tokyo and Anchorage, which highlighted the difficulty for airline users when two or more VAACs issue advisories for volcanic ash clouds caused by the same eruption individually without adequate coordination. In such cases, users need to obtain and monitor two advisories for one event. If the advisories have a gap that cannot be ignored, users will have difficulty in understanding the situation.

As the volcanic ash cloud moved to the southeast and approached VAACs Washington and Montreal, those VAACs also issued transfer VAAs. When an ash cloud is approaching within 300 nautical miles from the boundary of areas of responsibility, VAACs to which the ash is approaching are required to transfer VAAs from a VAAC with volcanic ash in its airspace (ICAO 2004). In this way, as the volcanic ash cloud covered a wide area over the boundaries of multiple VAACs' areas of responsibility, not only the volcanic ash cloud itself but also the situation that multiple VAACs issued VAAs and/or VAGs for its respective area of responsibility had an impact on users (JMA/VAAC Tokyo 2014; NOAA/VAAC Anchorage 2015b; NOAA/VAAC Washington 2015).

\section{Particular Challenges of International Coordination in Volcanic Ash and Visions of the Future}

As volcanic ash clouds flow regardless of borders, international cooperation/coordination is indispensable. Smooth communication between VAACs as well as among all the related organizations is essential in order to ensure safety. It is essential for volcano observatories, MWOs and VAACs to provide information on volcanic eruptions and sequential volcanic ash cloud diffusions to users such as airlines, civil aviation authorities, and relevant organizations in a way that users can grasp the situation easily. Users need to prepare effective risk management procedures and protocols for such cases. Close coordination/communication between information providers and users is required for smooth response against volcanic ash cloud emissions. Both information providers and users need to be prepared for various types of cases considering volcano locations, eruption duration, volcanic ash cloud propagation and coverage, as preferable responses may differ for each type. Adding to such preparation, a language skill is also required. As English is the standard international aviation language, some organizations in nonnative English speaking countries encounter a language barrier that makes it difficult to coordinate/communicate smoothly, speedily and in detail.

Therefore, both information providers and users have been undertaking various efforts regarding the requirements, including efforts of eliminating language barriers. This section introduces some of the particular challenges being addressed by them. 
(a)

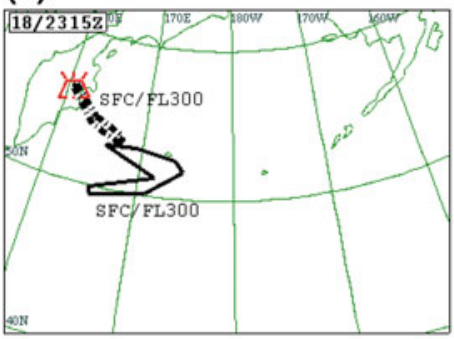

(b)
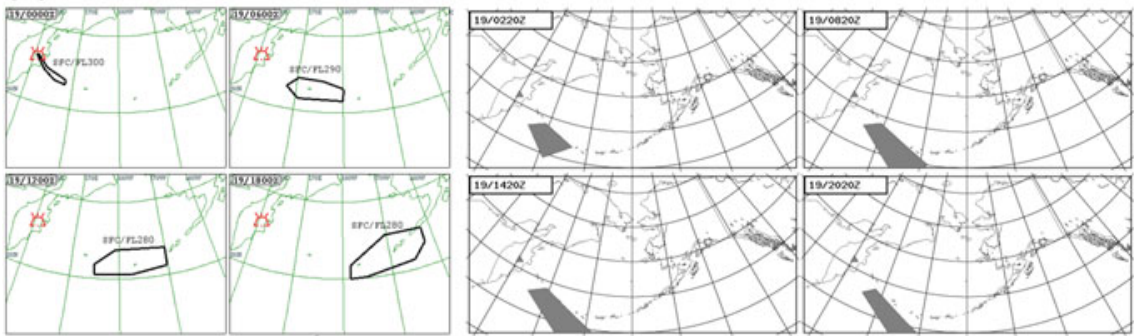

(c)
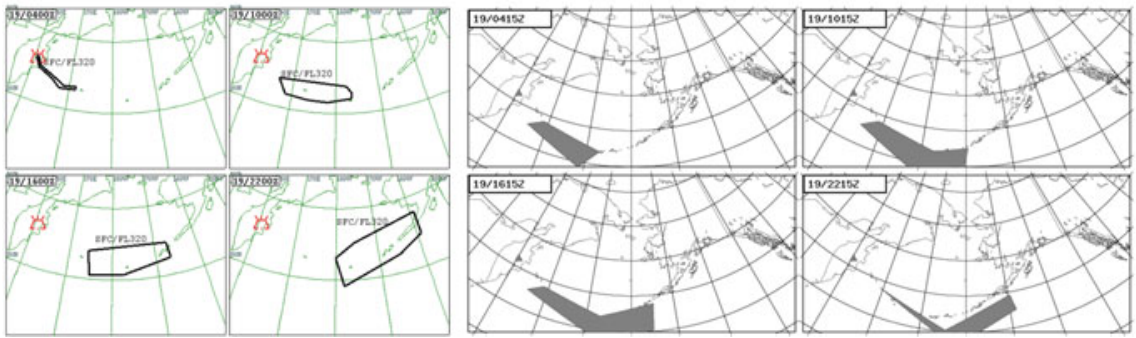

Fig. 4 a Observed (present) volcanic ash cloud extent in a left top of a VAG from VAAC Tokyo before handover which was issued at 23:59 UTC on 18 October 2013. The volcanic ash cloud area surrounded by a dotted line was in VAAC Tokyo's region and that surrounded by a solid line was in VAAC Anchorage's region. b VAGs from VAACs Tokyo (left) and Anchorage (right) after the handover for the same volcanic ash cloud issued at 00:54 UTC and

Challenges being taken by information providers

When a volcanic ash cloud flows from the area of responsibility of a certain VAAC to another, the responsibility to issue VAAs is to be handed over. This situation frequently occurs between VAACs Tokyo and Anchorage: when a volcano in Kamchatka or Kuril Islands erupts, the volcanic ash cloud often migrates into the area of responsibility of VAAC Anchorage. VAAC Tokyo then hands over its responsibility to VAAC Anchorage. One important aspect to note here is, aircraft need to
02:20 UTC on 19 October 2013, respectively. From these issuances, the VAACs started to provide VAA/VAGs for the volcanic ash cloud in their respective areas of responsibility individually. The volcanic ash extent in the VAGs had a big gap especially for forecasts at 12 and $18 \mathrm{~h}$ ahead. c VAGs from the VAACs at 04:45 UTC and 04:15 UTC on 19 October 2013, respectively. The gap in the VAGs became smaller but still inconsistency remained

continue their flights across the Northern Pacific region under a consistent risk management approach, regardless of which VAAC is responsible. Therefore, the forecast extent of volcanic ash clouds in VAA/VAGs from VAAC Tokyo before a handover and from VAAC Anchorage after the handover should not have inconsistencies. Considering the frequent occurrence of a handover as well as the necessity of providing consistent advisories between the two VAACs before and after the handover, there are particular challenges in coordination. 


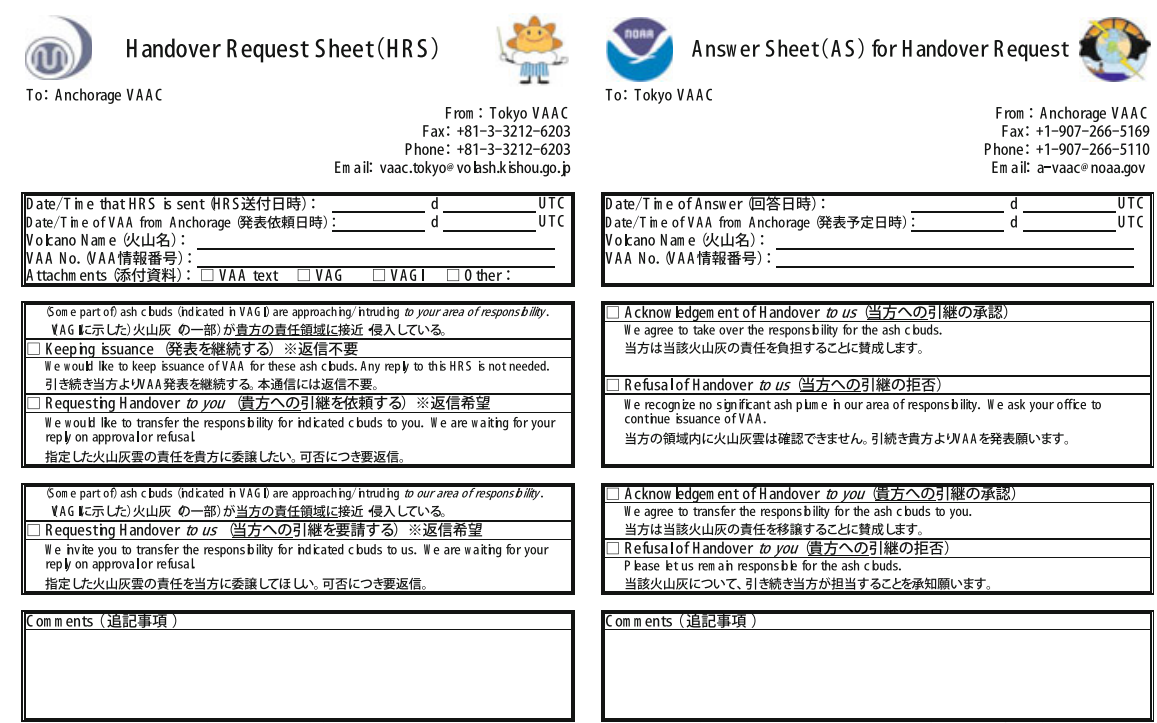

Fig. 5 Handover request sheet used between VAACs Anchorage and Tokyo. Necessary items for handover procedures are already in the sheet both in English and Japanese

\section{HANDOVER PROCEDURES BETWEEN \\ THE VOLCANIC ASH ADVISORY CENTRES ANCHORAGE AND TOKYO}

May 06, 2015

Fig. 6 Guideline of handover procedures. Criteria to conduct a handover is documented for eruption types such as single (short duration) eruptions, intermittent eruptions

(1) Guideline of handover procedures

VAACs Anchorage and Tokyo have prepared a specific form called "Handover Request Sheet and continuous eruptions with a volcanic ash cloud moving to the east, south or west

(HRS)" in which necessary items are already included both in English and Japanese (Fig. 5). When a case that requires a handover occurs, the VAACs complete necessary parts on the sheet 
Handover procedures from Tokyo to Anchorage

- Type 3: Continuous (long duration) eruption (case 2: propagating eastward) -

Condition: some part of an ash cloud due to a continuous eruption diffuses eastward, crosses the boundary of the AoRs from the Tokyo VAAC's side and approaches the meridian of $180 \mathrm{E}$ longitude.

Handover: the Tokyo VAAC requests a hand-over to the Anchorage VAAC and the Anchorage VAAC sends back an AS.

Further action in case the Anchorage VAAC accepts the request:

the Tokyo VAAC issues a VAA stating in RMK that some part of the volcanic ash cloud has moved out of its AoR and it notifies the necessity of checking VAAs both from the Tokyo and Anchorage VAAC. Once a handover is done, both VAACs will issue VAAs only for the ash cloud in their own AoR, regardless of $180 \mathrm{E}$.

Note: even after some parts of the ash cloud crosses the boundary of the AORs, the Tokyo VAAC basically continues to issue a VAA for the whole ash cloud until it approaches $180 \mathrm{E}$ considering the convenience for users, though there may be some exceptional cases.
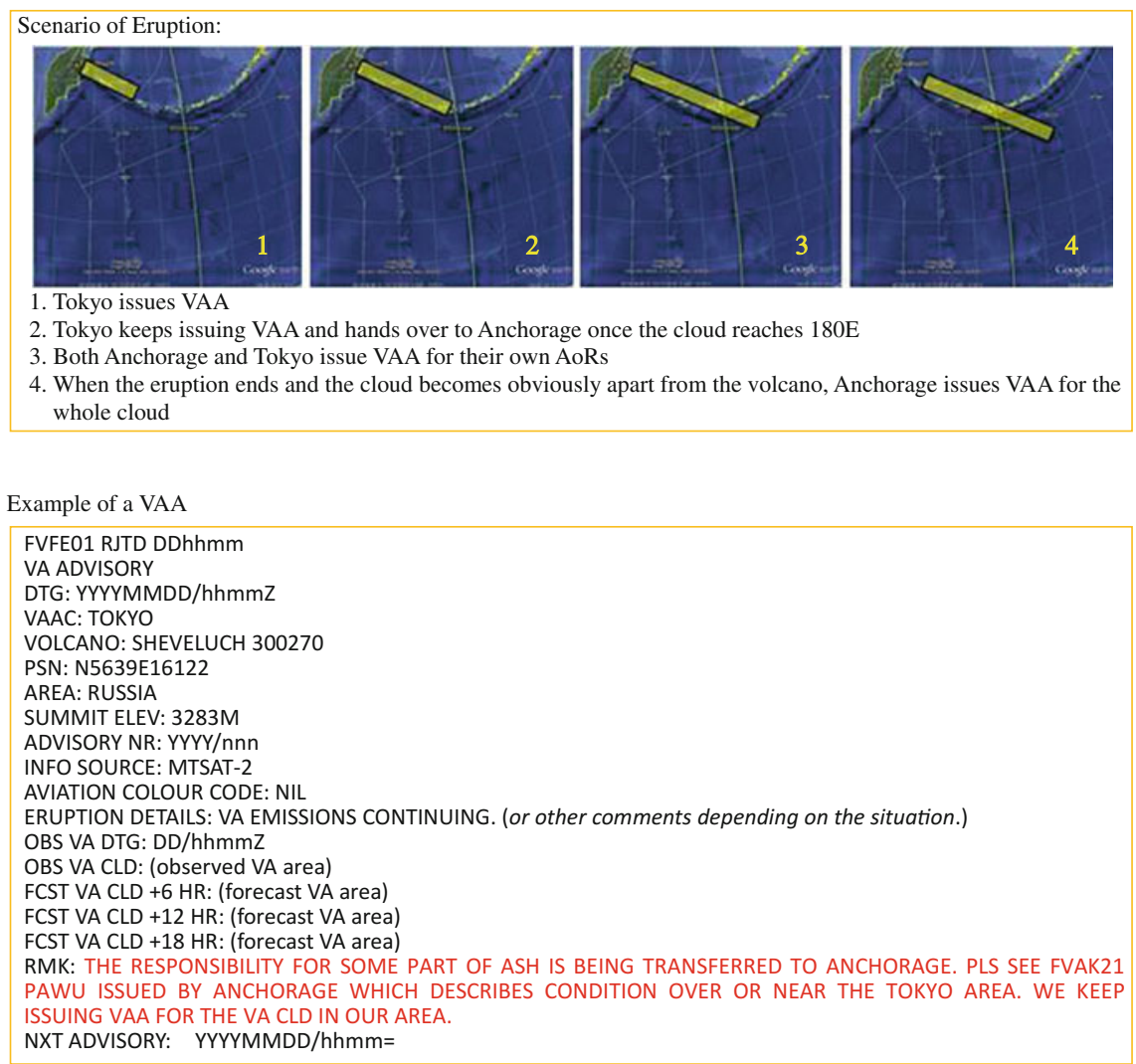

Fig. 6 continued

and exchange it in order to simplify and speed up the procedures. Additionally, the two VAACs, in advance, shared information on decision-making criteria on how and when to conduct handover procedures. This is because the timing to handover may well be different between VAACs depending on the situation, especially when a volcanic ash cloud extends across the areas of responsibility of both VAACs. The criteria have been coordinated and documented as a guideline (Fig. 6) in order that both VAACs can expect beforehand how the other centre will act with 
Handover procedures from Tokyo to Anchorage

- Type 3: Continuous (long duration) eruption (case 3: propagating southward) -

Condition: some part of an ash cloud due to a continuous eruption diffuses southward, crosses the boundary of the AoRs from the Tokyo VAAC's side and is expected to enter the AoR of the Washington VAAC.

Handover: the Tokyo VAAC requests a hand-over to the Anchorage VAAC and the Anchorage VAAC sends back an AS. The Tokyo VAAC informs the Washington VAAC of the situation.

Further action in case the Anchorage VAAC accepts the request:

the Tokyo VAAC issues a VAA stating in RMK that some part of the volcanic ash cloud has moved out of its AoR and it notifies the necessity of checking VAAs from the Tokyo, Anchorage and Washington VAAC.

Note: even after some parts of the ash cloud crosses the boundary of the AORs, the Tokyo VAAC basically continues to issue a VAA for the whole ash cloud. Discussion on heights and areal coverage of the plume will be held whenever necessary in order to reach a reasonable agreement between Anchorage and Tokyo.
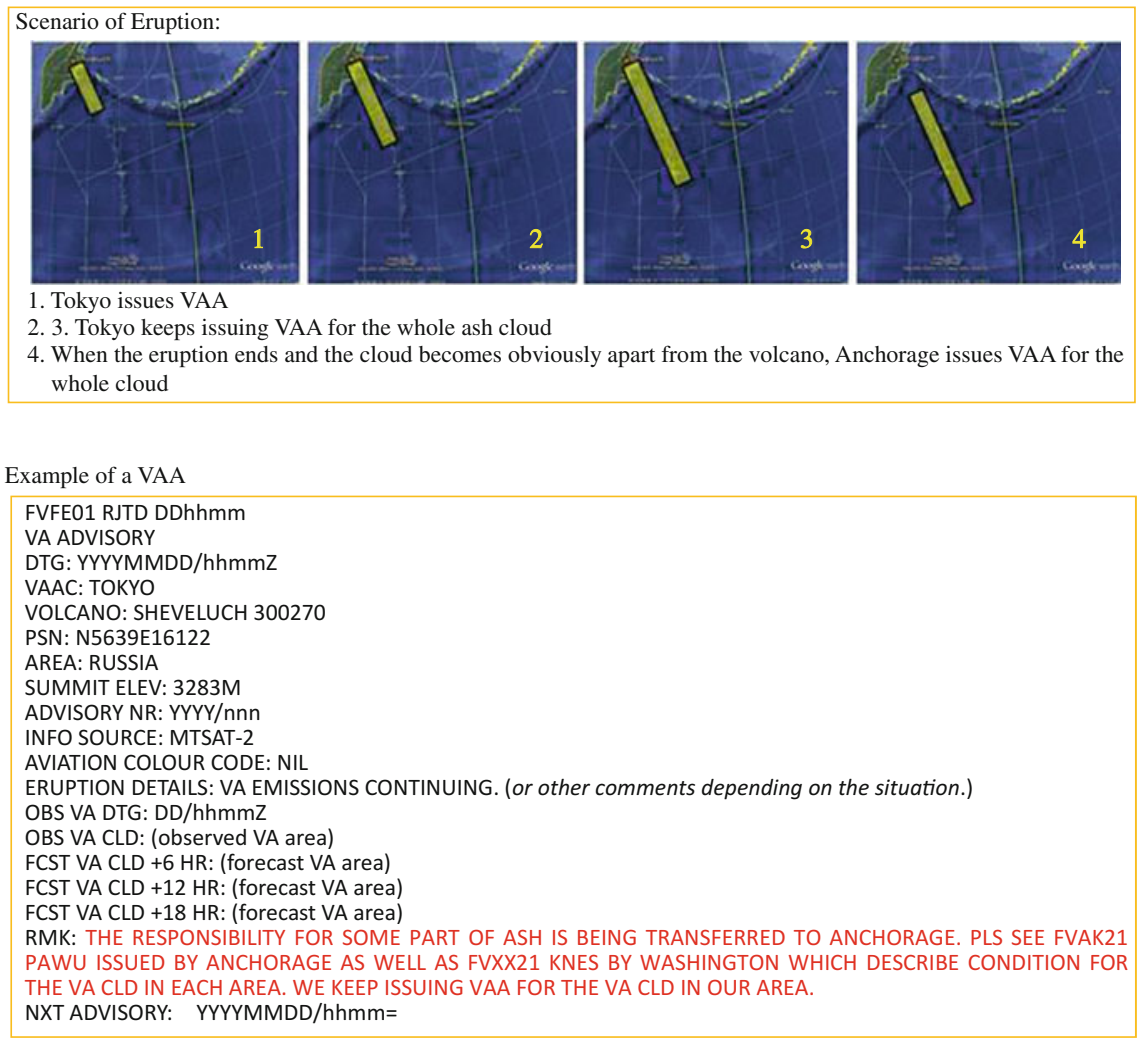

Fig. 6 continued

volcanic ash clouds moving towards/across the border of their areas of responsibility.

As described in the case study of the eruption of Kliuchevskoi Volcano in 2013, it is not user-friendly if two VAACs provide VAA/VAGs with a volcanic ash cloud area for their own individual areas of responsibility and/or if VAA/VAGs from two VAACs are inconsistent. Therefore, for continuous eruptions, VAACs Anchorage and Tokyo agreed to issue VAA/VAGs from one VAAC as much as possible even after the volcanic ash cloud area 


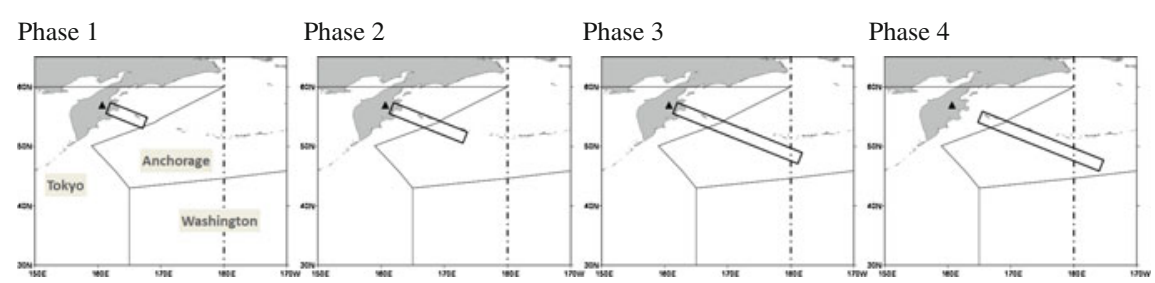

Fig. 7 Handover procedures for a continuous eruption at a volcano in VAAC Tokyo's area of responsibility with a volcanic ash cloud extending to the east. Triangle and rectangle indicate a volcano and a volcanic ash cloud area, respectively. The boundary of VAACs is drawn with a solid line and $180^{\circ} \mathrm{E}$ is drown with a dotted line. Phase 1: volcanic ash cloud is in VAAC Tokyo's area of responsibility and VAAC Tokyo issues VAA/VAG. Phase 2: volcanic ash cloud migrated into VAAC Anchorage's area of responsibility extending from the

extends across the boundary of their areas of responsibility.

For example, when a volcanic ash cloud, due to a continuous eruption at a certain volcano in VAAC Tokyo's airspace, extends to the east crossing the boundary of the areas of responsibility and covers a large area from the volcano to VAAC Anchorage's region, VAAC Tokyo continues to issue advisories for the entire volcanic ash cloud until it reaches $180^{\circ} \mathrm{E}$ so that airlines can grasp the current and future extent of volcanic ash cloud from VAA/VAGs provided by one VAAC (Tokyo). When it crosses $180^{\circ}$, VAAC Tokyo hands over the responsibility to VAAC Anchorage for a part of the volcanic ash cloud which has migrated into VAAC Anchorage's region. The VAACs cannot avoid providing VAA/VAGs from the two VAACs for a while, but once the eruption ends and the volcanic ash cloud separates from the volcano, VAAC Tokyo immediately conducts a handover for the entire volcanic ash cloud to VAAC Anchorage (Fig. 7).

When a volcanic ash cloud from a continuous eruption at a certain volcano in VAAC Tokyo's airspace extends to the south crossing the boundary of VAACs Tokyo and Anchorage's areas of responsibility and/or VAACs Anchorage and Washington's regions, VAAC Tokyo continues to issue advisories for the entire volcanic volcano in VAAC Tokyo's region, but it remains west of $180^{\circ} \mathrm{E}$, so VAAC Tokyo issues VAA/VAG for the entire volcanic ash cloud. Phase 3: volcanic ash cloud crossed $180^{\circ} \mathrm{E}$ so both VAACs Anchorage and Tokyo issue VAA/VAGs for their own areas of responsibility. Phase 4: eruption ended with volcanic ash cloud obviously apart from the volcano, so VAAC Tokyo conducts a handover and VAAC Anchorage issues VAA/VAGs for the entire volcanic ash cloud

ash cloud with necessary coordination with the other two VAACs about the height and extent of the volcanic ash cloud. The timing of handover varies, depending on the situation in this case, but when the eruption ends and the volcanic ash cloud moves to the south separated from the volcano, it is agreed that VAAC Tokyo immediately hands over the responsibility for the entire volcanic ash cloud to VAAC Anchorage, and VAAC Anchorage sequentially conducts a handover to VAAC Washington if the volcanic ash cloud still exists and is moving to the south (Fig. 8).

When a continuous eruption at a certain volcano in VAAC Anchorage's airspace produces a volcanic ash cloud to the west migrating into VAAC Tokyo's area of responsibility, VAAC Anchorage will continue issuing VAA/VAGs until it reaches $160^{\circ} \mathrm{E}$, though this situation seldom occurs. Then, if the volcanic ash cloud continues moving to the west across $160^{\circ} \mathrm{E}$ and migrates into VAAC Tokyo's region, VAAC Anchorage hands over the responsibility for a part of the volcanic ash cloud that crossed $160^{\circ} \mathrm{E}$ to VAAC Tokyo. In the same way as mentioned previously, once the eruption ends and the volcanic ash cloud moves to the west separated from the volcano, VAAC Anchorage immediately conducts a handover for the entire volcanic ash cloud to VAAC Tokyo (Fig. 9). 


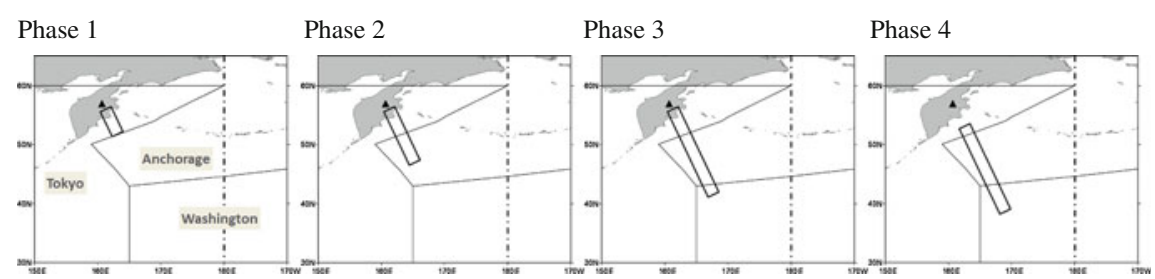

Fig. 8 Handover procedures for a continuous eruption at a volcano in VAAC Tokyo's area of responsibility with a volcanic ash cloud extending to the south. Triangle and rectangle indicate a volcano and a volcanic ash cloud area, respectively. The boundary of VAACs is drawn with a solid line and $180^{\circ} \mathrm{E}$ is drown with a dotted line. Phase 1: volcanic ash cloud is in VAAC Tokyo's area of responsibility and VAAC Tokyo issues VAA/VAG. Phase 2-3: volcanic ash cloud migrates in neighbouring
VAACs' areas of responsibility but is still extending from the volcano in VAAC Tokyo's region, so VAAC Tokyo issues VAA/VAGs for the entire volcanic ash cloud with necessary coordination among the relevant VAACs for its height and extent. Phase 4: eruption ended with volcanic ash cloud obviously apart from the volcano, so VAAC Tokyo conducts a handover and VAAC Anchorage issues VAA/VAGs for the entire volcanic ash cloud

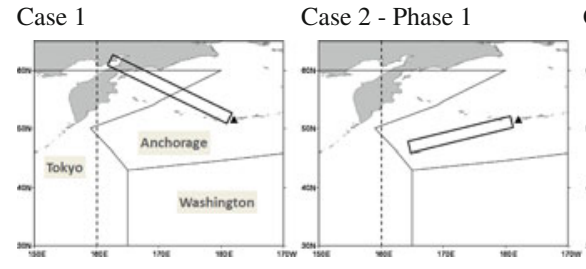

Fig. 9 Handover procedures for a continuous eruption at a volcano in VAAC Anchorage's area of responsibility with a volcanic ash cloud extending to the west. Triangle and rectangle indicate a volcano and a volcanic ash cloud area, respectively. The boundary of VAACs is drawn with a solid line and $160^{\circ} \mathrm{E}$ is drown with a dotted line. Case 1: volcanic ash cloud migrates into VAAC Tokyo's area of responsibility extending from the volcano in VAAC Anchorage's region, but it remains east of $160^{\circ} \mathrm{E}$, so VAAC Anchorage continues issuing VAA/VAGs for the entire volcanic ash cloud. Case 2: (Phase 1) volcanic ash

Information sharing on decision-making criteria is also done for single (short duration) eruptions and intermittent eruptions. The procedures for single (short duration) eruptions are more straight-forward. VAACs Anchorage and Tokyo agreed to hand over the entire volcanic ash cloud when more than half of it has migrated into the neighbouring VAAC's area of responsibility. The procedures for intermittent eruptions are also relatively straight-forward, because intermittent eruptions are, as it were, repeated single eruptions. VAACs agreed to repeat the procedures for single eruptions applying to newer ash clouds generated by intermittent eruptions.

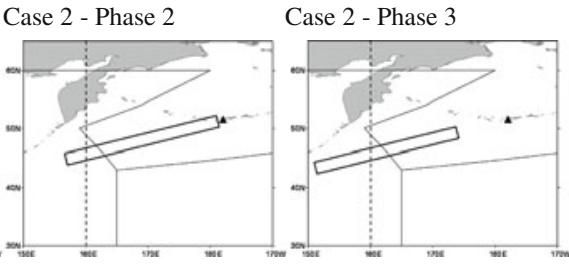

cloud is in VAAC Anchorage's area of responsibility and VAAC Anchorage issues VAA/VAG. (Phase 2) volcanic ash cloud crosses $160^{\circ} \mathrm{E}$ and VAAC Anchorage conducts a handover for a part of the volcanic ash cloud that has migrated in VAAC Tokyo's region. Both VAACs Anchorage and Tokyo issue VAA/VAGs for their own areas of responsibility. (Phase 3) eruption ended with volcanic ash cloud obviously apart from the volcano, so VAAC Anchorage conducts a handover and VAAC Tokyo issues VAA/VAGs for the entire volcanic ash cloud

(2) Challenge to collaborative decision analysis and forecast via chat system

In order to provide consistent advisories before and after the handover, it is better to share forecasters' thoughts before volcanic ash clouds actually cross the border of the areas of responsibility, especially for a complicated or exceptional situation. Therefore, VAACs Anchorage and Tokyo have started testing a chat system for closer and more flexible communication. NOAA has provided its proprietary chat system and created an account for this challenge (Osiensky et al. 2014). As part of the test, the VAACs are 
aiming at finding necessary specific patterns of phenomena as well as phrases of questions and answers corresponding to them, and creating a template like a frequently-asked questions-sheet so that the communication will be smooth between members including non-native English speakers.

The first test was held in July 2014 based on a scenario of the past eruption at Kliuchevskoi in October 2013, in which a volcanic ash cloud moved far southeast. As the VAA/VAGs were not user-friendly in those days as described earlier, the VAACs prepared a scenario following the current guidelines on handover procedures introduced previously that had been established between them in spring 2014, as shown in Fig. 6, and conducted the test. The second test was held in December 2014 based on a scenario of the eruption at Sheveluch in September 2014, in which a volcanic ash cloud moved to the north and where the timing of dissipation was not clear. The third test was held in July 2015 based on a scenario of the eruption at Sheveluch in March 2015 , in which a volcanic ash cloud moved to the south and migrated into both VAACs Anchorage and Washington's areas of responsibility. Not only VAACs Anchorage and Tokyo but also VAAC Washington took part in the third test to check if communication/coordination among the three VAACs would work well via a chat system. After that, operational use of the chat system was utilized on a trial basis instead of through scheduled tests that required coordination ahead of time. If this trial proves to be successful and becomes fully operational in these VAACs, it could be used as a model case and applied to coordination/communication, not only between VAAC Tokyo and other organizations, but between other VAACs and volcano observatories particularly in the area where English is not the native language.

\section{Challenges being taken by information users}

The cooperation/coordination introduced before is undertaken by VAACs essentially as information providers. Considering the importance of international cooperation and coordination mentioned earlier, Volcanic Ash Exercises are conducted in some regions under the framework of ICAO. The first exercise was established in ICAO European and North Atlantic (EUR/NAT) region called the VOLCEX and has been conducted since 2008. Realizing the effectiveness of the VOLCEX, a similar exercise in the EUR (EAST) Region including Kamchatka Peninsula started in 2013 recognising that this region experiences frequent volcanic eruptions that often affect aviation operations especially around the NOPAC routes. Therefore, an exercise in this region, named VOLKAM, has been conducted and is making good progress in coordination procedures between all participating parties (air navigation service providers, air traffic management centres, aeronautical information services, volcano observatories, VAACs, MWOs and users such as airlines). So far, VOLKAM has been held every year: the first exercise was held from 21:00 UTC on January 15, 2013 to 06:00 UTC on January 16, 2013, the second one from 21:00 UTC on March 4, 2014 to 04:00 UTC on March 5, 2014 and the third one from 22:00 UTC on April 15, 2015 to 04:00 UTC on April 16, 2015. The exercises have a different focus each time and participants test new challenges during the exercises (ICAO 2014a, b, 2015a, b; JCAB 2015).

In addition to the volcanic ash exercises, when airlines make a detour at an actual eruption, they need to coordinate with relevant organizations for re-routing. The Cross Polar Trans East Air Traffic Management Providers Working Group (CPWG) is dealing with the topic of international coordination for re-routing and JCAB is one of the members of CPWG.

The following are examples of the challenges being met by participants of the exercises including airlines, and/or members of CPWG.

(1) Determination of a re-route according to a scenario and a matrix on a response for a re-routing request

Once a notification of an eruption is received by a dispatcher, the potential impact to flights that are already en-route is evaluated and if the impact 
is expected, re-routing procedures will be taken. Re-routing should be conducted immediately because an encounter with a volcanic ash cloud may cause a fatal accident; even a small amount of volcanic ash can cause enormous financial costs with respect to repairing engines and other parts. As all flights in the volcanic ash-affected region undertake re-routing procedures, it should be well organized to accommodate all of them in a limited number of routes, considering the issue of remaining fuel. Additionally, there are regulations and/or restrictions in each State, such that re-routing options are not always accepted. Hence, it is quite effective to prepare a possible contingency route based on an assumed eruption in advance, even if it is a paper-plan and only used during an exercise. As this route has cleared the political issue and other conditions (like a fuel amount), it could be a realistic alternative route in case of a sudden eruption, surely saving time in coordination and implementation.

However, procedures for responding to a request for re-routing are not currently standardized as described in the case study for the eruption of Sarychev-Peak Volcano in 2009; they differ depending on the ANSP. It may be better if a standardized procedure among all ANSPs is prepared, but this is difficult because of various restrictions in each country, and it will take time to achieve. For example, airlines expect re-routing procedures for aircraft in flight to be conducted using the Air Traffic Service Communication (ATSC) via air traffic control centres, while the ground system of air traffic control centres in some countries cannot process re-routing messages from aircraft in flight because transaction between pilots and air traffic controllers are prioritized. Another example is that some countries apply a license system and requires aircraft to obtain permission from an authorized organization when they fly over particular airspaces. If an aircraft requests re-routing over such countries in order to avoid volcanic ash cloud, it needs to obtain permission that will take time. Therefore, before pursuing this ideal to prepare a standardized procedure among all ANSPs, it has been set as a primary goal to create a matrix on each ANSP's status when it receives a request for re-routing so that airlines can easily grasp the present situation. This work originated from the volcanic ash exercise VOLKAM. Currently the task has been dealt with in the framework of CPWG, so all the members of CPWG including FAA and JCAB can work on this issue. In addition, it is also regarded as an important aspect to consider how to enable organizations related to the matrix to obtain the volcanic eruption information; this is an on-going task as well. The matrix may be tested in VOLKAM sometime in the future once a draft version is prepared (ICAO 2014a, b).

\section{(2) Use of VOLKAM sheet}

Similar to the collaborative decision analysis and forecast via a chat system being conducted between VAACs Anchorage, Tokyo and Washington, a spreadsheet named VOLKAM Sheet, prepared by JCAB/ATMC, was workshopped by participants of the volcanic ash exercise in 2015, in an effort to organize relevant information in one sheet chronologically and reduce the issue of language barriers. The VOLKAM Sheet contains chronological information on a present situation for the eruption phase, volcanic ash cloud area, influence in traffic flow and aircraft operations based on the volcanic ash cloud conditions, as well as the information about the expected coordination and actions among the relevant organizations such as a flow control of aircraft, resetting PACOTS and the timing of the next VAA/VAG, and other information issuances. A remarks column is prepared in the sheet in case there are any special notes to share (Fig. 10).

During the exercise, each organization sent this VOLKAM Sheet to all participants via e-mail, with an organization name and a version number so that everybody understood which spreadsheet was the latest one to add new information about the present situation and/or planned actions. The usability of this sheet to improve situation awareness among the relevant organizations was tested during the exercise in 2015. The participants understood the idea that it would be better to prepare a communication method rather than a phone call, considering that 


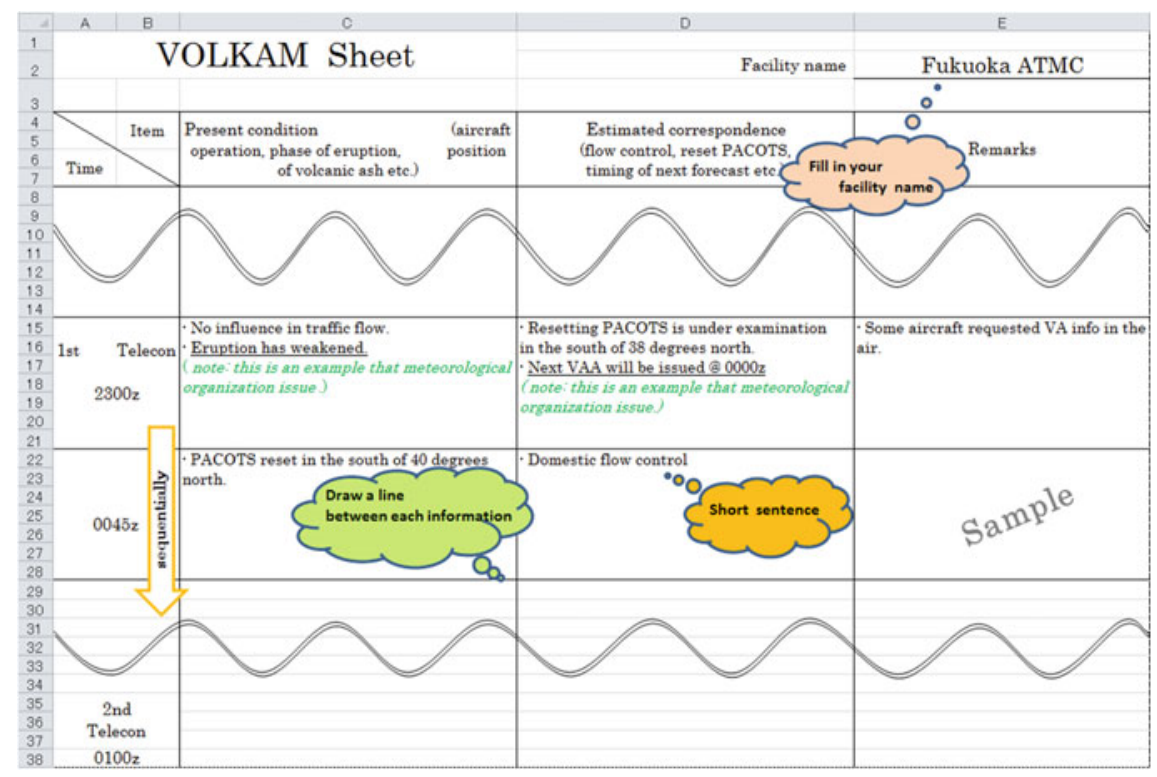

Fig. 10 VOLKAM Sheet used in the volcanic ash exercise in 2015: it was prepared by JCAB/ATMC with columns for the information on a present situation, expected actions and remarks. Participants of the exercise put some information that they have and shared the sheet during the exercise. Information was added in order of time

ash accumulation at airports. As volcanic ash may cause a fatal accident and also as it crosses borders, it is essential to provide coherent and consistent volcanic ash-related information to airlines, civil aviation authorities, MWOs and other relevant organizations to avoid aviation disasters. Hence, international cooperation and coordination with the efforts of meteorological, volcanological and civil aviation authorities from multiple countries is indispensable.

Along with the requirement for proper information issuances and smooth coordination among relevant organizations, various efforts have been taken in some regions. As for the Northern Pacific region, volcanoes in Kamchatka Peninsula are remarkably active: this brings particular challenges for related organizations because a volcanic ash cloud frequently moves across the boundary of VAACs Tokyo and Anchorage's areas of responsibility. They need to conduct handover procedures whenever it occurs, and especially when the volcanic ash cloud covers the NOPAC routes, ATMCs, ACCs and airlines coordinate for re-routing.
Volcanic ash cloud can seriously affect aircraft and air services by causing engine failure, poor visibility due to ash-related scouring of aircraft windshields and take-off/landing delays due to

\section{Summary}


Among recent eruptions, those of SarychevPeak Volcano in 2009 and Kliuchevskoi Volcano in 2013 are introduced in this chapter as examples to illustrate successes and ongoing challenges of international eruption response coordination.

In this respect, VAACs Anchorage and Tokyo are working on a smoother handover and consistent information issuances using English. JCAB/ATMC and other aviation-related organizations are making similar efforts in a volcanic ash exercise in 2015 to grasp all the relevant information in one sheet in chronological order. The aim is to overcome language barriers, using a VOLKAM Sheet mainly for discussion on re-routing by sharing the present situation of the eruption phase, volcanic ash area, influence onto the traffic flow and aviation operations, as well as the expected coordination and actions by relevant organizations. The planning process itself for re-routing in the exercise is also meaningful: that will contribute to shorten the time required for coordination in a real case. In addition, an effort to share the present situation of each ANSP, responding to a re-routing request, by creating a matrix on such information has begun; members of CPWG are working on this task aiming at establishing a standardized procedure among all the ANSPs, as a long-term ideal outcome.

In this way, the volcanic ash- and/or aviationrelated organizations will continue their work seeking for better coordination and operations, respectively.

Acknowledgements Information as for the on-going efforts in JCAB given by Mr. Takayuki Harada, the deputy chief air traffic controller in JCAB, has been a great help to flesh out the article as well as making it well-balanced in highlighting efforts taken by both information providers and users.Some of the figures were created using Generic Mapping Tools open-source software (GMT; Wessel, P. and W.H.F. Smith, New, improved version of Generic Mapping Tools released, EOS Trans. Amer. Geophys. U., Vol. 79, No. 47, p. 579, 1998).

\section{References}

Anchorage AK (2015a) Volcanic Ash Advisory Center, the National Oceanic and Atmospheric Administration (NOAA/VAAC Anchorage) AAWU_Volcanic Ash
Advisory Center. Retrieved 7 Aug 2015, from http:// vaac.arh.noaa.gov/vaac_info.php

Anchorage AK (2015b) Volcanic Ash Advisory Center, the National Oceanic and Atmospheric Administration (NOAA/VAAC Anchorage) VAAs/VAGs. Retrieved 7 Aug 2015, from http://vaac.arh.noaa.gov/list_vaas. php

Girina OA, Romanova IM (2015) Activity of Kamchatkan and Northern Kuriles volcanoes database of Kamchatkan Volcanic Eruption Response Team. In: 26th IUGG general assembly, 22 June-02 July 2015. IUGG/IAVCEI, Prague, P. VS10p-456

Girina OA, Manevich AG, Malik NA, Melnikov DV, Ushakov SV, Demyanchuk YuV, Kotenko LV (2007) Active volcanoes of Kamchatka and Northern Kurils in 2005. J Volcanol Seismolog 1(4):237-247

Girina OA, Ushakov SV, Malik NA, Manevich AG, Melnikov DV, Nuzhdaev AA, Demyanchuk YuV, Kotenko LV (2009) The active volcanoes of Kamchatka and Paramushir Island, North Kurils in 2007. J Volcanol Seismolog 3(1):1-17

Girina OA, Manevich AG, Melnikov DV, Demyanchuk YuV, Petrova E (2014a) Explosive eruptions of Kamchatkan volcanoes in 2013 and danger to aviation, EGU2014. Austria, Vienna

Girina OA, Manevich A, Melnikov D, Nuzhdaev A, Demyanchuk Y (2014b) Activity of Kamchatkan volcanoes in 2012-2013 and danger to aviation. In: International workshop "JKASP-8", Sapporo, Japan. 22-26 Sept 2014

Gordeev EI, Girina OA (2014) Volcanoes and their hazard to aviation. Herald Russ Acad Sci 84(2):134142

ICAO (2004) Handbook of the international airways volcano watch (IAVW), 2nd edn, from http://www. icao.int/publications/Documents/IAVW\%20Hand book\%20Doc\%209766_en.pdf

ICAO (2007) ICAO annex 3 meteorological service for international air navigation, 16th edn, from http://www. wmo.int/pages/prog/www/ISS/Meetings/CT-MTDCFET-DRC_Geneva2008/Annex3_16ed.pdf

ICAO (2014a) Summary of discussions of the eighteenth meeting of the cross polar trans east air traffic management providers working group (draft version) from https://www.faa.gov/about/office_org/headquarters_ offices/ato/service_units/systemops/ato_intl/documents/ cross_polar/CPWG19/CPWG19_WP02_CPWG18_ Summary_of_Discussions.pdf

ICAO (2014b) Summary of discussions of the VOLKAM14 Debrief \& EUR (EAST) VOLCEX/ SG/4 Meetings

ICAO (2015a) Exercise directive for volcanic ash exercise in Kamchatka in 2015 (VOLKAM15)

ICAO (2015b) Outcomes from other ICAO volcanic ash exercises from http://www.icao.int/APAC/Meetings/ 2015\%20VOLCEX_SG1/IP02_ICAO\%20AI.3\%20-\% 20Outcomes $\% 20$ from $\% 20$ other $\% 20$ ICAO $\% 20$ VA $\% 20$ exercises.pdf

JCAB (2015) VOLKAM15 outcomes at JCAB from http:// www.icao.int/APAC/Meetings/2015\%20VOLCEX_ 
SG1/SP03_Japan\%20-\%20VOLKAM15-Outcomes. pdf

KVERT/Volcano Observatory Notification to Aviation (KVERT/VONA) (2013) Retrieved 7 Aug 2015, from http://www.kscnet.ru/ivs/kvert/van/index.php

McGimsey RG, Neal CA (1996) 1995 volcanic activity in Alaska and Kamchatka: summary of events and response of the Alaska Volcano Observatory, U.S. Geological Survey Open-File Report OF 96-0738, 22 p

McGimsey RG, Wallace KL (1999) 1997 volcanic activity in Alaska and Kamchatka: summary of events and response of the Alaska Volcano Observatory, U.S. Geological Survey Open-File Report OF 99-0448, 42 p

McGimsey RG, Neal CA, Girina OA (2003) 1998 volcanic activity in Alaska and Kamchatka: summary of events and response of the Alaska Volcano observatory, open-file report 2004-1033. Department of the Interior, U.S. Geological Survey, U.S, p 35

McGimsey RG, Neal CA, Girina OA (2004a) 1999 volcanic activity in Alaska and Kamchatka: summary of events and response of the Alaska Volcano observatory, open-file report 2004-1033. Department of the Interior, U.S. Geological Survey, U.S, p 45

McGimsey RG, Neal CA, Girina OA (2004b) 2001 volcanic activity in Alaska and Kamchatka: summary of events and response of the Alaska Volcano Observatory, open-file report 2004-1453. Department of the Interior, U.S. Geological Survey, U.S, p 53

McGimsey RG, Neal CA, Girina OA (2005) 2003 volcanic activity in Alaska and Kamchatka: summary of events and response of the Alaska Volcano Observatory, open-file report 2005-1310. Department of the Interior, U.S. Geological Survey, U.S, p 58

McGimsey RG, Neal CA, Dixon JP, Ushakov SV (2008) 2005 volcanic activity in Alaska, Kamchatka, and the Kurile Islands: summary of events and response of the Alaska Volcano observatory, U.S. Geological Survey Scientific Investigations Report 2007-5269, 94 p

McGimsey RG, Neal CA, Dixon JP, Malik NV, Chibisova MV (2011) 2007 volcanic activity in Alaska, Kamchatka and the Kurile Islands: summary of events and response of the Alaska Volcano observatory, U.S. Geological Survey Scientific Investigations Report 2010-5242, 110 p

McGimsey RG, Neal CA, Girina OA, Chivisova MV, Rybin AV (2014) 2009 volcanic activity in Alaska, Kamchatka, and the Kurile Islands: summary of events and response of the Alaska Volcano observatory, U.S. Geological Survey Scientific Investigations Report 2013-5213, $125 \mathrm{p}$

Neal CA, McGimsey RG (1997) 1996 volcanic activity in Alaska and Kamchatka: summary of events and response of the Alaska Volcano Observatory, U.S. Geological Survey Open-File Report OF 97-0433, 34 p

Neal CA, McGimsey RG, Chubarova OS (2004) 2000 volcanic activity in Alaska and Kamchatka: summary of events and response of the Alaska Volcano observatory, U.S. Geological Survey Open-File Report OF 2004-1034, 37 p

Neal CA, McGimsey RG, Dixon JP, Melnikov DV (2005a) 2004 volcanic activity in Alaska and Kamchatka: summary of events and response of the Alaska Volcano Observatory, U.S. Geological Survey Open-File Report 2005-1308, 71 p

Neal CA, McGimsey RG, Girina OA (2005b) 2002 volcanic activity in Alaska and Kamchatka: summary of events and response of the Alaska Volcano Observatory, Open-File Report 2004-1058. Department of the Interior, U.S. Geological Survey, U.S, p 55

Neal CA, Girina OA, Senyukov SL, Rybin AV, Osiensky J, Izbekov P, Ferguson G (2009a) Russian eruption warning systems for aviation. Nat Hazards 51(2):245-262

Neal CA, McGimsey RG, Dixon JP, Manevich AG, Rybin AV (2009b) 2006 volcanic activity in Alaska, Kamchatka, and the Kurile Islands: summary of events and response of the Alaska volcano observatory, U.S. Geological Survey Scientific Investigations Report 2008-5214, $102 \mathrm{p}$

Neal CA, McGimsey RG, Dixon JP, Cameron CE, Nuzhdaev AA, Chibisova MV (2011) 2008 volcanic activity in Alaska, Kamchatka, and the Kurile Islands: summary of events and response of the Alaska Volcano Observatory, U.S. Geological Survey Scientific Investigations Report 2010-5243, 94 p

Neal CA, Herrick J, Girina OA, Chivisova MV, Rybin AV, McGimsey RG, Dixon JP (2014) 2010 volcanic activity in Alaska, Kamchatka, and the Kurile Islands: summary of events and response of the Alaska Volcano Observatory, U.S. Geological Survey Scientific Investigations Report 2014-5034, 76 p

Osiensky J, Moore D, Igarashi Y (2014) Moving toward a globally harmonized volcanic ash forecast system: anchorage and Tokyo VAAC best practices on collaboration, AGU fall meeting from https://agu. confex.com/agu/fm14/meetingapp.cgi\#Paper/27123

Tokyo Volcanic Ash Advisory Center, The Japan Meteorological Agency (JMA/VAAC Tokyo) (2010) Volcanic ash advisories (2009), from http://ds.data.jma. go.jp/svd/vaac/data/Archives/2009_vaac_list.html

Tokyo Volcanic Ash Advisory Center, The Japan Meteorological Agency (JMA/VAAC Tokyo) (2014) Volcanic ash advisories (2013), from http://ds.data.jma. go.jp/svd/vaac/data/Archives/2013_vaac_list.html 
Tokyo Volcanic Ash Advisory Center, The Japan Meteorological Agency (JMA/VAAC Tokyo) (2015) The roles of the Tokyo VAAC. Retrieved 7 Aug 2015, from http://ds.data.jma.go.jp/svd/vaac/data/Inquiry/ vaac_operation.html
Washington Volcanic Ash Advisory Center, The National Oceanic and Atmospheric Administration (NOAA/ VAAC Washington) (2015) Washington VAAC 2009 volcano ash advisory archive, from http://www.ssd. noaa.gov/VAAC/ARCH09/archive.html
Open Access This chapter is licensed under the terms of the Creative Commons Attribution 4.0 International License (http://creativecommons.org/licenses/by/4.0/), which permits use, sharing, adaptation, distribution and reproduction in any medium or format, as long as you give appropriate credit to the original author(s) and the source, provide a link to the Creative Commons license and indicate if changes were made.
The images or other third party material in this chapter are included in the chapter's Creative Commons license, unless indicated otherwise in a credit line to the material. If material is not included in the chapter's Creative Commons license and your intended use is not permitted by statutory regulation or exceeds the permitted use, you will need to obtain permission directly from the copyright holder. 